\title{
The Implementation of Blended Learning Method on Chemistry Students' Motivation in Learning English
}

\author{
$1^{\text {st }}$ Rezky Uspayanti* \\ Department of English Education \\ Universitas Musamus \\ Merauke, Indonesia \\ rezky05@unmus.ac.id \\ $4^{\text {st }}$ Ranta Butarbutar \\ Department of English Education \\ Universitas Musamus \\ Merauke, Indonesia \\ ranta@unmus.ac.id
}

\author{
$2^{\text {st }}$ Marni Bawawa \\ Department of English Education \\ Universitas Musamus \\ Merauke, Indonesia \\ marnibawawa@unmus.ac.id \\ $5^{\text {st }}$ Seli Marlina Raja Leba \\ Department of English Education \\ Universitas Musamus \\ Merauke, Indonesia \\ selly@unmus.ac.id
}

\author{
$3^{\text {st }}$ Martha Betaubun \\ Department of English Education \\ Universitas Musamus \\ Merauke, Indonesia \\ marthabetaubun@unmus.ac.id
}

\begin{abstract}
This study aimed to investigate the use of Blended Learning method on students' motivation in learning English. The participants of this study namely the first semester of Chemistry students in Musamus University. This study is qualitative study which focused on descriptive qualitative study. The sample was chosen by using purposive sampling. In taking the data, the researcher used observation, questionnaire and interview. The observation consisted on preobservation and post-observation to see the students' motivation before and after implemented blended learning. Thus, interview was also used which consisted on 7 questions. In making the data more valid, the researchers gave questionnaire about their motivation in learning English after using blended learning. The questionnaire consisted of 15 questions. Based on the observation was done by researchers, the students were more attractive in learning English using blended learning method. The results of interview showed that most students agree and were motivated in learning English by using handbook for face to face learning and using learning video and e-material for non face to face learning (blended learning method). Furthermore, for the results of questionnaire, most students also gave positive responds for the implementation of blended learning in teaching and learning process.
\end{abstract}

Keywords: blended learning, motivation, learning English, chemistry students

\section{INTRODUCTION}

Learning method is one main factor in teaching and learning process. The way in teaching must be packed in good ways in order attract motivation and interest. Generally, ideal learning will be created from variation and innovation. In this globalization era, the teacher or lecturer must do changing, one of them is creating effective teaching concept. Teacher should be able to find an easy relationship about something that will be taught to make it easier for students to capture that information. Thus, along with the advancement of Information and communication technology (ICT), the learning approach also changes. In that connection, today's learning activities are rapidly expanding by involving technology. Along with the development of technology, especially the information technology (Internet), the paradigm of educators as a center of information starts to change, because the Internet provides a wide range of information and is not limited [1]. Thus, learning approach has changed towards future learning or as a century of knowledge learning. People can learn anywhere, anytime, and with anyone. The quality of teacher/lecturer should be increased, not only the knowledge but also the creativity. This means that they should do the improvement the quality of the learning process.

Blended learning method is one innovation which is done by the teacher to create innovative teaching. In-face online learning can be combined through a blended learning system. Blended learning strategies are part in using technological advances in the quality improvement. The rapid advancement of technology affects the changing education and learning, learning technology has adopted and adapted these cutting-edge findings into the learning process. Blended learning is one of the new learning strategies that provide a lot of benefits for students, as well as a form of information technology support and communication towards new learning mode [2]. Term of blended learning appear when [3] states that web-based learning can be combined with face-to-face learning. The term of blended learning has been used by education institution especially in college [4], but there are still many people that confused on that term. Blended learning directs to a systematic approach in combining times and modes of learning, integrating the best aspects of face-to-face and online interactions for each discipline and using appropriate ICTs. Video describes how blended learning combines classroom environments and face-to-face settings, with digital tools and environments [5]. Thus, [5] also mentioned if it is flexible learning and teaching experiences involving assessment, teacher-student communication, student activities, teaching activities and students resources. If Blended Learning is well implemented, 
this learning model will contribute positively to the learning process [6].

English is international language and it is very important in this technology era. By knowing English, the students will be easy to get better job and other thing. In learning English, the students still confused to understand the material, especially for non-English students such as Chemistry students who learn English as general course in University. Thus, they did not have motivation in learning English because they think if English is not their specific. The low motivation on students will affect on their ability in English, because motivation increase on learning performance and speed of work. Based on observation, the low motivation affect because there is not handbook for them as the tool in learning English. So, we as the lecture or teacher should create new innovation to make the students interesting in learning English or foreign language especially for nonEnglish department students. One solution is introducing blended learning. Teaching English language can be useful for students by using blended learning because it is about how to manner class can be active and it blends the traditional teaching classroom and modern teaching classroom [7]. [8], learning a foreign language show different challenges for different people in different situation. Based on the explanation, innovative, various approaches and method should be used to introduce new language for non English students and also introduce variety classroom management technique in maximizing teaching and learning process.

Data based on observation, almost of foreign language teaching is done in classroom and the maximal learning goal poses a significant challenge in most foreign language teaching situations that the students have limitation chance to actively engage in using the target language [9]. In this study, the researcher combined two ways namely face-toface meeting and non face-to-face meeting. For face to face ways, the researcher gave English module namely "English for Chemistry" for the students in chemistry department and non face to face way, the researcher gave learning video related to the material and online material which was served in form of online Google classroom. Online learning activities, included in blended learning, can improve the students' motivation and interest in learning process.

According to the study, it focused on blended learning and motivation. [10]Blended Learning is a learning that combines various web-based technologies, to achieve educational objectives. It is also as a learning approach that integrates between face-to-face and online learning to produce a more effective learning experience. Blended learning system is used to promote the learning with integration of visual cues and educational concepts [2], and it also goals at using modern technology in teaching and also focus on direct interaction in the classroom through using modern communication mechanism [11]. With regards to the composition of the learning implementation, blended learning strategies apply $50 \%$ face to face, $25 \%$ offline (through self-learning with interactive media), and $25 \%$ online (learning by using the Web), The composition is applied taking into consideration the characteristics of students as well as lecturers who have never implemented this learning strategy before [12]. Moreover, in blended learning, the teacher/lecturer is the active speaker where as in online learning students are centre of teaching and learning process to achieve curriculum diversity [13]. Based on the explanation about blended learning from some experts, the researchers concluded if blended learning is the combination of face to face meeting and non-face to face meeting using online learning or web-based technology.

Related to motivation, there are some experts who have given the definition of motivation. [14] said that motivation is as the complex part from human behaviour and psychology, it is affect on how individuals choose to invest their time, how much the energy used, how they think and feel about task. Furthermore, the motivation of someone is very important in establishing the activity in learning, because the people or groups who have motivation will be more successful than those who do not have the motivation [15]. The other expert that gave the definition of motivation namely [16], she said that motivation is behaviour which is signed by willingness and desire, the motivation consisted of intrinsic and extrinsic motivation. Intrinsic motivation consist personal enjoyment, interest, or pleasure while extrinsic motivation is governed by reinforcement contingencies. Based on the explanation from some experts, the researchers concluded that motivation is as the stimulus of someone which affect on his success. Someone who has high motivation in learning will be easy to be success in learning while someone who has low motivation in learning English; she/he will be difficult to catch the material in learning.

\section{RESEARCH METHODS}

\section{A. Research Design}

This study is descriptive qualitative research. Descriptive method is a method which explain or describe subject or object of the study, it describe a phenomena toward problem clearly, thus it used suitable procedure in order the purposes can be reached [17]. Therefore, [18], qualitative research is the collection, analysis, interpretation of comprehensive narrative and visual data in order to gain the insight into a particular phenomenon of interest. This study wants to know the students' motivation in learning English for non English students/chemistry students. Explanation of the research result was made in the form of descriptive so the readers get the complete information from the research result.

\section{B. Research Site and Participants}

The study was conducted in Musamus University which focused on the second semester of Chemistry Education Department, Faculty of Teacher Training and Education. The researcher applied purposive sampling technique. [19]Sugiyono in Hamzah states that a purposive sampling technique is one of the techniques that used to determine the subjects by considering something or criteria.

\section{Research Instrument}

The researcher applied some kinds of instrument in this research namely observation, interview and questionnaire. The observations used were pre observation was to know the students motivation in learning English before implementing blended learning and post observation was to know the students motivation after implementing blended learning. Thus, questionnaire consisted of 15 questions. It was used to know their responds toward blended learning in learning English on their motivation. In making the data 
more valid, the researchers gave interview which consisted of 7 questions.

\section{Technique of Collecting Data and Data Analysis}

The technique in collecting the data, there were some steps which were done by researchers. Firstly, pre observation, it was done to see the students' motivation before implemented blended learning method or paid attention the students' motivation in learning English by using conventional method. Then, do the observation after implemented blended learning method. Thus, the researchers interviewed students to know their responds about the use of blended learning method in teaching and learning process. In interview the students, researchers used audio and video recording. To make the data more valid, the questionnaire was given. It consisted on 15 questions. Analyzing data from interview used qualitative data analysis based on Miles and Huberman's theory [20] which consisted of three stages: data reduction, data display and conclusion verification.

\section{RESULTS AND DISCUSSION}

The result of this study covered data analysis about the enhancement of students' motivation in learning English for Chemistry students department. The data was taken by doing observation, giving questionnaire and interview the second semester students of Chemistry department in Universitas Musamus.

\section{A. Result of Observation}

Based on observation before introducing blended learning, most students were boring in learning English. They did not interest in learning English because it was not their specific. They were boring with the way of lecturer in teaching English by using conventional method. They were less attractive to learn English because they did not have specific handbook. By the result of pre-observation, the researchers introduced blended learning in teaching English for Chemistry students. The researcher gave "English for Chemistry" module as handbook for students in face to face learning while for non face to face meeting, the researcher gave learning video and gave material in Google classroom for non face to face meeting. After introduce and implemented blended learning, the researcher observed the students. The result showed that, the students was more attractive in learning English by using handbook thus the handbook connecting to chemistry vocabulary. Moreover, they were learning English using learning video in their home. In taking the data, the researchers also used interview and Questionnaire. The interview did to know the students responds on the use of handbook, learning video and Google classroom in learning English.

\section{B. Result of Interview}

Based on interview, most students gave positive responds on the use of blended learning in learning English. Some of them said if the use of handbook combine with learning video motivated them in learning English, they said that using blended learning attract them. They did not feel boring again. By using learning video, they will see that video in their home as repetition about the material that has been explained. One of results of interview that has been translated in English can be seen below:
Interviewer : What do you know about blended learning method?

Student : Combination of two ways in learning.... e...namely direct meeting and non face to face meeting

Interviewer : Do you feel happy and motivated in learning English by using module for face to face meeting?

Student : Yes of course

Interviewer : Do you feel happy and motivated in learning English by using learning video for non face to face meeting and also the use of Google classroom?

Student : Yes,

Interviewer : Why?

Student $\quad:$ Mmmm... because learning video is not boring, we can see the video many times e'.... to improve our knowledge related to material. Exactly we are happy in learning English. About the Google classroom, mmm... it is also a good way, so we are not late about that material. We get the material although the lecture is busy and cannot come to the meeting.

Interviewer : How do you think of blended learning that is a combination of face to face using module drafts and non face to face with learning video in English language learning?

Student : I like that method, e'....because by combination of two ways, we can be easy to understand the material.

Interviewer : Is the combination of a draft module on face to face meeting and learning video on non face to face meeting making you happy and motivated in learning English?

Student : Yes, because draft module and learning video is interesting tool to understand the material.

Interviewer : Is the combination of a draft module on face to face meeting and learning video on non face to face meeting making you easy in understand the material?

Student : Yes,

Interviewer : Why?

Student: Because by using draft module as handbook in learning process, make us easy to understand the material. E'...we can see material in printed material. If we forget, we can see the material in draft module, so we remembered again. With the use of draft module while the lecturer explain the material, of course we are easy to understand the material especially for us who is non English students. Mmm... with the use of learning video, we can see the video many times. That is way helping in remember the material.

Interviewer : Does the material given in Google classroom improve your understanding in learning English.

Student : Yes, because the material that is given is simple and based on what has been explained in face to face meeting. 


\section{Result of Questionnaire}

To support the data of oral interview and observation, the researchers distributed questionnaire to know the responds of Chemistry students toward the use of blended learning method on their motivation. The researchers gave questionnaire which consisted of 15 questions related to blended learning and motivation. There are 15 statements in questionnaire were given. Moreover, the percentage results can be seen in the table 1 .

Based on the table, the result shows that most respondents agree on the use of blended learning method in
English module helps me to understand the material". For this statement, $64.3 \%$ respondents are strongly agree and $35.7 \%$ respondents are agree. For the second statement "Learning English with modules makes me motivated", 7.1\% respondent is strongly agree and $92.9 \%$ are agree. Thus, "I am happy with the use of module in learning English", $14.3 \%$ respondents are strongly agree and $85.7 \%$ respondents are agree. For the statement "the English module used related to chemistry. $71.4 \%$ respondents are strongly agree and $28.6 \%$ are agree.

\begin{tabular}{|c|c|c|c|c|c|}
\hline Statement & $\begin{array}{c}\text { Strongly } \\
\text { Agree }\end{array}$ & Agree & $\begin{array}{c}\text { Less } \\
\text { Agree } \\
\end{array}$ & Disagree & $\begin{array}{l}\text { Strongly } \\
\text { Disagree }\end{array}$ \\
\hline The use of English module helps me to understand the material & $64.3 \%$ & $35.7 \%$ & & & \\
\hline Learning English with modules makes me motivated & $7.1 \%$ & $92.9 \%$ & & & \\
\hline The English module used related to chemistry & $71.4 \%$ & $28.6 \%$ & & & \\
\hline $\begin{array}{l}\text { The use of learning video for non face to face meeting improve the motivation } \\
\text { in English learning process }\end{array}$ & $14.3 \%$ & $42.9 \%$ & $28.6 \%$ & $14.3 \%$ & \\
\hline I am happy with the use of learning video for non-face to face meeting & $14.3 \%$ & $50 \%$ & $21.4 \%$ & $14.3 \%$ & \\
\hline $\begin{array}{l}\text { The use of learning video for non face to face meeting improve the } \\
\text { understanding toward English }\end{array}$ & & $64.3 \%$ & $28.6 \%$ & $7.1 \%$ & \\
\hline $\begin{array}{l}\text { The material that is served in Google classroom for non face to face improve } \\
\text { the understanding toward English }\end{array}$ & $14.3 \%$ & $50 \%$ & $35.7 \%$ & & \\
\hline $\begin{array}{l}\text { The material that is served in Google classroom for non face to face meeting } \\
\text { improve motivation toward English }\end{array}$ & $21.4 \%$ & $35.7 \%$ & $42.9 \%$ & & \\
\hline I am happy with the use of Google classroom & $21.4 \%$ & $42.9 \%$ & $35.7 \%$ & & \\
\hline The use of blended learning helps to understand English material & $28.6 \%$ & $64.3 \%$ & & $7.1 \%$ & \\
\hline $\begin{array}{l}\text { The combination of module in face to face meeting and learning video for non } \\
\text { face to face meeting motivated me in learning English }\end{array}$ & $50 \%$ & $21.4 \%$ & $21.4 \%$ & $7.1 \%$ & \\
\hline $\begin{array}{l}\text { I am happy with the combination of module for face to face meeting and } \\
\text { learning video for non face to face meeting in learning English }\end{array}$ & $35.7 \%$ & $50 \%$ & $14.3 \%$ & & \\
\hline $\begin{array}{l}\text { The combination of module, learning video and Google classroom increase the } \\
\text { motivation in learning English }\end{array}$ & $42.9 \%$ & $50 \%$ & & 7.1 & \\
\hline
\end{tabular}

learning English. For the first statement namely "The use of

\section{TABLE I. THE PERCENTAGE OF QUESTIONNAIRE RESULT}

Based on the table above, the result shows that most respondents agree on the use of blended learning method in learning English. For the first statement namely "The use of English module helps me to understand the material". For this statement, $64.3 \%$ respondents are strongly agree and $35.7 \%$ respondents are agree. For the second statement "Learning English with modules makes me motivated", $7.1 \%$ respondent is strongly agree and $92.9 \%$ are agree. Thus, "I am happy with the use of module in learning English", $14.3 \%$ respondents are strongly agree and $85.7 \%$ respondents are agree. For the statement "the English module used related to chemistry. $71.4 \%$ respondents are strongly agree and $28.6 \%$ are agree.

For item 5 "The use of learning video for non face to face meeting improve the motivation in English learning process", $14.3 \%$ respondents are strongly agree, $42.9 \%$ respondents are agree, $28.6 \%$ are less agree and $14.3 \%$ are disagree. For item 6 "I am happy with the use of learning video for non-face to face meeting", $14.3 \%$ respondents are strongly agree, $50 \%$ respondents are agree, $21.4 \%$ respondents are less agree and $14.3 \%$ are disagree. Moreover, for statement "The use of learning video for non face to face meeting improve the understanding toward English", there were $64.3 \%$ respondents who are agree, $28.6 \%$ are less agree and $7.1 \%$ respondent is disagree. For statement "The material that is served in Google classroom for non face to face improve the understanding toward English", $14.3 \%$ respondents are strongly agree, 50\% respondents are agree and $35.7 \%$ respondents are less agree. For item 9 "The material that is served in Google classroom for non face to face meeting improve motivation toward

English", 21.4\% respondents are strongly agree, $35.7 \%$ are agree and $42.9 \%$ respondents are less agree. For item 10 "I am happy with the use of Google classroom", 21.4\% respondents are strongly agree, $42.9 \%$ are agree and $35.7 \%$ are less agree.

Item 11 "The use of blended learning helps to understand English material “, $28.6 \%$ respondents are strongly agree, $64.3 \%$ respondents are agree and $7.1 \%$ is disagree. Item 12 namely "The combination of module in face to face meeting and learning video for non face to face help in understanding English material", 35.7\% respondents are strongly agree, $50 \%$ respondents are agree, $7.1 \%$ is less agree and disagree. Next, for statement "The combination of module in face to face meeting and learning video for non face to face meeting motivated me in learning English", $50 \%$ respondents are strongly agree, $21.4 \%$ respondents are agree and less agree, $7.1 \%$ is disagree. For statement "I am happy with the combination of module for face to face meeting and learning video for non face to face meeting in 
learning English", 35.7\% respondents are strongly agree, $50 \%$ are agree and $14.3 \%$ respondents are less agree. For the last statement namely "The combination of module, learning video and Google classroom increase the motivation in learning English", 42.9\% respondents are strongly agree, $50 \%$ are agree, and $7.1 \%$ is disagree.

\section{CONCLUSION}

As the conclusion, from the result of observation, the respondents were motivated and happy with the use of blended learning method in learning English. The result of interview also showed if the respondents gave positive responds of blended learning method. The same results also showed from the result of questionnaire that the respondents were agree with the implementation of blended learning method. There were 15 statements given. Item 1, $64.3 \%$ respondents are strongly agree and $35.7 \%$ respondents are agree. For item 2, 7.1\% respondents are strongly agree and $92.9 \%$ are agree. Item 3,14.3\% respondents are strongly agree and $85.7 \%$ respondents are agree. For item $4,71.4 \%$ respondents are strongly agree and $28.6 \%$ are agree. The other questions of questionnaire almost respondents were agree of the use of blended learning in learning English.

\section{ACKNOWLEDGMENT}

The big gratitude is given to Rector and Dean FKIP of Universitas Musamus for their support, chance, guide and suggestions. The researchers also gave the big thanks for respondents namely the second semester of chemistry students department who have been as the respondents.

\section{REFERENCES}

Y. Yendra, W. Satria, and W. Rahmat, "Model Blended Learning Untuk Mata Kuliah Introduction To Linguistics Pada Prodi Pendidikan Bahasa Inggris Stkip Pgri Sumbar,” J. Ipteks Terap., 2017.

[2] C. R. Graham, "Blended learning systems: Definition, current trends, and future directions," in Handbook of blended learning: Global perspectives, local designs, 2006.

[3] M. Kerres and C. De Witt, "A Didactical Framework for the Design of Blended Learning Arrangements," J. Educ. Media, 2003.

[4] R. Kuntarto, Eko dan Asyhar, "Pengembangan Model Pembelajaran Blended Learning pada Aspek Learning Design dengan Platform Media Sosial Online sebagai Pendukung Perkuliahan Mahasiswa," Keefektifan Metod. Inq. Terhadap Keaktifan Dan Has. Belajar Siswa Kelas X Pembelajaran Kim., 2016.

[5] G. Saliba, L. Rankine, and H. Cortez, "The Fundamentals of Blended Learning," Univ. West. Sydney, 2013.

[6] L. S. Brew, "The role of student feedback in evaluating and revising a blended learning course," Internet High. Educ., 2008.

[7] I. F. Sari, A. Rahayu, D. I. Apriliandari, and D. Sulisworo., "Blended Learning: Improving Student's Motivation in English Teaching Learning Process. International Journal of Languages' Education and Teaching.," 2018.

[8] D. Marsh, "Blended Learning - Creating Learning Opportunities for Language Learners," Cambridge Univ. Press, 2012.

[9] Mahalli, J. Nurkamto, J. Mujiyanto, and I. Yuliasri, "The Implementation of Station Rotation and Flipped Classroom Models of Blended Learning in EFL Learning," English Lang. Teach., 2019.

[10] M. Driscoll, "Blended Learning: Let's Get beyond the Hype. IBM Global Services.," 2002.

[11] T. I. Oweis, "Effects of Using a Blended Learning Method on Students' Achievement and Motivation to Learn English in
Jordan: A Pilot Case Study," Educ. Res. Int., vol. 2018, p. 7425924, 2018

[12] S. Sudarman, "Pengaruh Strategi Pembelajaran Blended Learning Terhadap Perolehan Belajar Konsep Dan Prosedur Pada Mahasiswa Yang Memiliki Self-Regulated Learning Berbeda," J. Pendidik. dan Pembelajaran, 2014.

[13] R. Shivam and S. Singh, "Implementation of Blended Learning in Classroom: A review paper. International Journal of Scientific and Research Publications, Volume 5, Issue 11.," 2015.

[14] R. Bakar, "The Effect of Learning Motivation on Student's Productive Competencies in Vocational High School, West Sumatra. International Journal of Asian Social Science.," 2014.

[15] O. Hamalik, Proses Belajar Mengajar. Jakarta: Bumi Aksara, 2002.

[16] E. R. Lai, "Motivation: A Literature Review. Research Report. Pearson.," 2011.

[17] I. Rosbaniar, "Pengembangan Bahan Ajar Bahasa Inggris Kelas Satu Berbasis Lingkungan untuk Meningkatkan Penguasaan Kosa Kata Siswa.," Universitas Pendidikan Indonesia., 2012.

[18] L. R. Gay, G. E. Mills, and P. W. Airasian, Educational research: Competencies for Analysis and Applications. New Jersey: Pearson Prentice Hall, 2006.

[19] A. Hamzah, "Analyzing the Use of Adjacency Pairs in Classroom Interaction. State University of Makassar. Unpublished Thesis.," 2015.

[20] M. B. Miles and M. A. Huberman, Analisis Data Kualitatif: Buku Sumber Tentang Metode-Metode Baru. 2012. 